\title{
Metacercariae of Eumegacetes medioximus (Digenea: Eumegacetidae) in larvae of Odonata from Brazil
}

\author{
Hudson Alves Pinto ${ }^{1,2}$ \& Alan Lane de Melo ${ }^{I}$ \\ ${ }^{1}$ Laboratório de Taxonomia e Biologia de Invertebrados, Departamento de Parasitologia, \\ Instituto de Ciências Biológicas, Universidade Federal de Minas Gerais - UFMG, CP 486, \\ CEP 30123-970, Belo Horizonte, MG, Brasil \\ ${ }^{2}$ Corresponding author: Hudson Alves Pinto, e-mail: hudsonalves13@ig.com.br
}

PINTO, H.A. \& MELO, A.L. Metacercariae of Eumegacetes medioximus (Digenea: Eumegacetidae) in larvae of Odonata from Brazil. Biota Neotrop. 13(2): http://www.biotaneotropica.org.br/v13n2/en/abstract?shortcommunication+bn03913022013

Abstract: During studies on the participation of larval Odonata in the life cycle of trematodes carried out at the Pampulha reservoir, Belo Horizonte, State of Minas Gerais, Brazil, between May and September 2011, dragonfly larvae, Orthemis discolor (Burmeister, 1839) and Perithemis mooma Kirby, 1889, were found harboring metacercariae identified as Eumegacetes medioximus Braun, 1901. This is the first report and morphological description of metacercariae of E. medioximus in the Neotropical region.

Keywords: trematodes, insects, dragonfly, parasites.

PINTO, H.A. \& MELO, A.L. Metacercárias de Eumegacetes medioximus (Digenea: Eumegacetidae) em larvas de Odonata no Brasil. Biota Neotrop. 13(2): http://www.biotaneotropica.org.br/v13n2/pt/abstract?shortcommunication+bn03913022013

Resumo: Durante estudos sobre a participação de larvas de Odonata no ciclo biológico de trematódeos realizados na represa da Pampulha, Belo Horizonte, Minas Gerais, Brasil, entre maio e setembro de 2011, larvas de libélulas, Orthemis discolor (Burmeister, 1839) e Perithemis mooma Kirby, 1889, foram encontradas apresentando metacercárias identificadas como Eumegacetes medioximus Braun, 1901. Este é o primeiro relato e caracterização morfológica de metacercárias de E. medioximus para a região neotropical.

Palavras-chave: trematódeos, insetos, libélula, parasitos. 


\section{Introduction}

The involvement of insects belonging to the order Odonata Fabricius, 1793 in the life cycle of digeneans has been known since the beginning of the twentieth century (Sinitsin 1905). Several digenean that parasitize birds and amphibians, such as the species of Eumegacetes Looss, 1900 (Eumegacetidae), Gorgoderina Looss, 1902 (Gorgoderidae), Haematoloechus Looss, 1899 (Plagiorchiidae), Halipegus Looss, 1899 (Derogenidae), and Prosthogonimus Lühe, 1899 (Prosthogonimidae), have been reported parasitizing dragonfly larvae as second intermediate or paratenic hosts in North America, Europe and Asia (Stafford 1931, Boddeke 1960, Hall 1960, Snyder \& Janovy Jr 1994, Kumari \& Madhavi 1994, Zelmer \& Esch 1998, Bolek \& Janovy Jr 2007, Bolek et al. 2010). Although several species of these helminths have been recorded as adult parasites in vertebrate hosts from Brazil (Travassos et al. 1969), there are no reports of natural infection of larval dragonflies by digeneans in this country.

In the present study the natural infection of larval dragonflies with metacercariae identified as Eumegacetes medioximus Braun, 1901 is reported for the first time in the Neotropical region.

\section{Material and Methods}

During malacological surveys conducted at the Pampulha reservoir (43 $59^{\prime} 35^{\prime \prime} \mathrm{W}$ and $19^{\circ} 50^{\prime} 50^{\prime}$ ' S), Belo Horizonte, Minas Gerais, Brazil, between May and September 2011, naiads of Odonata belonging to the suborder Anisoptera were collected using a hand net and transported alive to the laboratory.

After morphological identification in accordance with Santos (1973), Costa et al. (2004) and Costa \& Santos (2009), the odonate naiads were teased apart using dissecting needles and examined for parasites under a stereomicroscope. The cysts recovered were initially studied in temporary mounts using light microscope. The metacercariae were mechanically excysted using metal needles, slightly pressed between glass slides, fixed in formalin at $70{ }^{\circ} \mathrm{C}$, stained with alum acetocarmine, dehydrated in an ascending series of alcohol, cleared in beechwood creosote and mounted in Canada balsam.

Photographs were obtained using a Leica ICC50 HD digital camera attached to a light microscope and measurements were obtained by analyzing the captured images using the Leica Application Suite (LAZ EZ) software, version 2.0. A drawing was made with aid of a camera lucida. The parasite was identified based on taxonomic keys and descriptions according Travassos et al. (1969) and Lotz \& Font (2008). Measurements are presented in micrometers. Specimens studied were deposited in the collection of the Invertebrate Taxonomy and Biology Laboratory (DPIC), Instituto de Ciências Biológicas, UFMG, Brazil.

\section{Results and Discussion}

Odonate naiads, identified as Orthemis discolor (Burmeister) and Perithemis mooma Kirby (Anisoptera: Libellulidae), had metacercariae in the abdominal cavity. Six similar cysts were found in the content of the proventriculus of a specimen of Striated Heron, Butorides striata (Linnaeus), found dead in the same locality. After morphological analysis and morphometry, the parasite was identified as belonging to the family Eumegacetidae Travassos, 1922 and the species characterized below.

\section{Eumegacetes medioximus Braun, 1901 (Figure 1 and 2)}

Synonyms: Eumegacetes perodiosus Travassos, 1922.

Stage: Metacercaria.

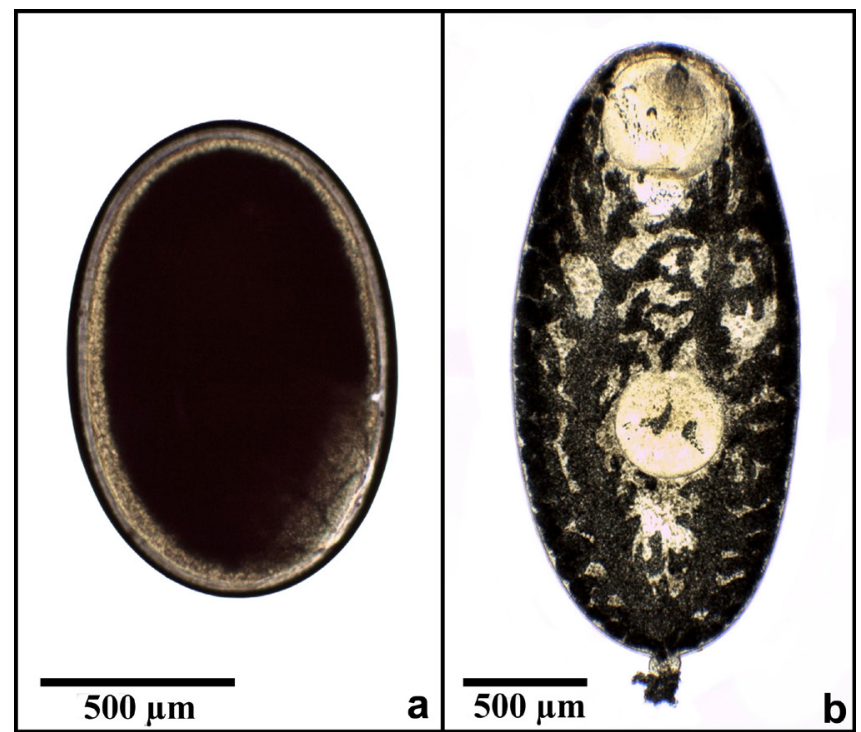

Figure 1. Metacercaria of Eumegacetes medioximus found in naiads of Odonata collected at the Pampulha reservoir, Belo Horizonte, Minas Gerais, Brazil. (a) Encysted. (b) Excysted. Unstained wet mount.

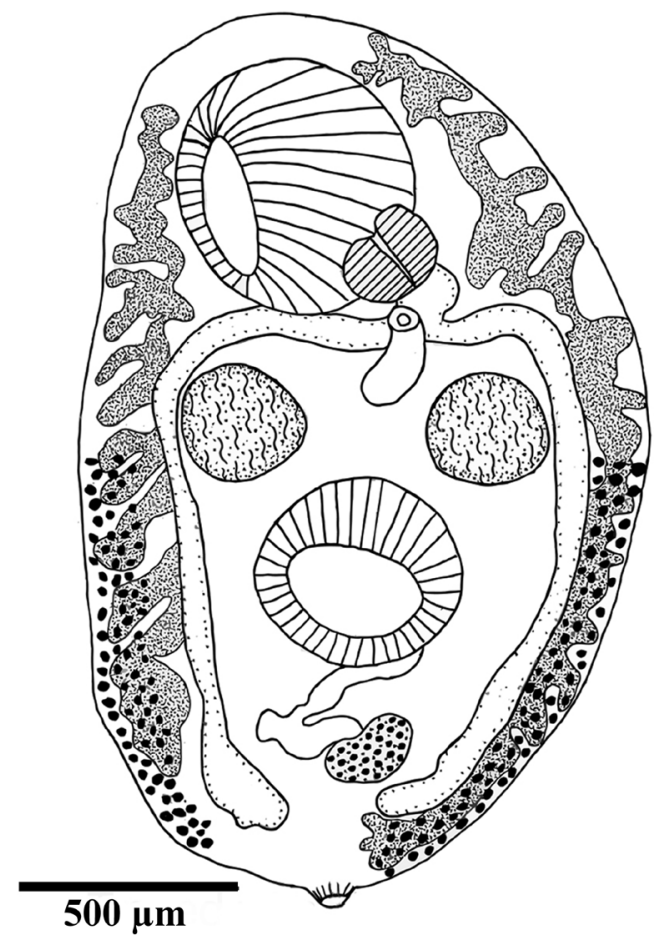

Figure 2. Line drawing of excysted metacercaria of Eumegacetes medioximus found in naiads of Odonata collected at the Pampulha reservoir, Belo Horizonte, Minas Gerais, Brazil.

Hosts: Orthemis discolor (Burmeister, 1839) and Perithemis mooma Kirby, 1889.

Site of infection: Hemocoel.

Locality: Pampulha reservoir, Belo Horizonte, State of Minas Gerais, Brazil.

Description: Cysts oval to spherical 1254 (1117-1375) in length by 1080 (840-1375) in width. Cystic membrane transparent measuring 45 (34-60) in thickness. Excysted metacercariae oval 1953 (1812-2137) in length by 1224 (937-1428) in width. Oral sucker 
subterminal, 529 (363-643) in length by 530 (362-643) in width. Ventral sucker equatorial, 353 (286-432) in length by 407 (296$590)$ in width. Oral sucker width to ventral sucker width ratio 1.52 (1.27-2.11). Prepharynx short. Pharynx muscular, 203 (142-226) in length by 242 (157-302) in width. Esophagus short. Intestinal caeca extending to the posterior portion of the body. Two testes spherical, opposite, pre-acetabular, intercaecal. Right testis 263 (154-326) in length by 237 (142-314) in width. Left testis 234 (142-307) in length by 233 (135-289) in width. Ovary round, post-acetabular, median, 176 (111-227) in length by 172 (110-204) in width. Vitellaria follicular, extracaecal, in two fields lateral, extending from posterior margin of testes to posterior extremity of body. Uterine primordium inconspicuous, seen only in the anterior region of ovary. Cirrus pouch oval to elongated, median, located in the anterior portion of body, 152 (144-177) in length by 84 (75-95) in width. Genital pore median, bifurcal. Excretory vesicle V- shaped, with arms reaching the level of the anterior region of body, presenting lateral diverticula and filled with dark granules. Excretory pore terminal.

Specimens deposited: DPIC 6220-6222

Remarks: Eumegacetes medioximus was described by Braun (1901) from material collected by Johann Natterer from the Great Jacamar, Galbula grandis Latham (Galbulidae), in Brazil in the mid-nineteenth century. It was subsequently recorded in several species of birds in the States of Mato Grosso do Sul and Rio de Janeiro in Brazil (Travassos 1928, Travassos \& Freitas 1940, Travassos et al. 1969, Brasil \& Amato 1992), and in Venezuela (Lutz 1928, Caballero \& Díaz-Ungría 1958). Except for the absence of eggs in the uterus, other morphological traits of the metacercariae studied in the present study are in accordance with reported by these authors. Recently, Eumegacetes sp. was found in sparrows, Passer domesticus (Linnaeus) (Passeridae), in the State of Rio Grande do Sul (Calegaro-Marques \& Amato 2010). Other developmental stages of $E$. medioximus were not previously known.

Members of Eumegacetidae are intestinal parasites of birds with worldwide distribution (Lotz \& Font 2008). The life cycle is known for Eumegacetes artammi Mehra, 1935, and Orthetrotrema monostomum Macy and Basch, 1972, and includes a prosobranch mollusc, Melanoides tuberculata (Müller) (Thiaridae), as intermediate host; xiphidiocercariae belonging to the microcotylous group emerge from infected molluscs and penetrate odonate larvae, to form metacercariae, in the case of $E$ artammi, or progenetic adults in O. monostomum (Kumari \& Madhavi 1994, Madhavi \& Swarnakumari 1995). Different species of dragonfly larvae have been reported harboring metacercariae of Eumegacetes in the United States of America (Stafford 1931, Hall 1960) and India (Rao \& Madhavi 1961, Singh \& Pande 1968, Prakash \& Pande 1970, Kumari \& Madhavi 1994). The present study is the first report of metacercariae of Eumegacetes in larvae of Odonata in the Neotropics.

The first intermediate hosts of E. medioximus remain unknown. Recently, a small xiphidiocercariae with morphological characteristics consistent with cercariae of Eumegacetidae known have been found in Pomacea lineata (Spix) (Ampullariidae) at the Pampulha reservoir (HAP, unpublished data), however experimental or molecular evidences are still necessary to confirm that these cercariae are conspecific with E. medioximus. Although M. tuberculata is the only intermediate host of Eumegacetes known so far, larvae of these parasites have not yet been reported in this thiarids in the Neotropical region (Pinto \& Melo 2011). Experimental infection studies are needed in order to elucidate the participation of these prosobranch molluscs in the transmission of E. medioximus.

Few studies have evaluated the involvement of aquatic insects in the biological cycle of digeneans in South America. Larvae of Odonata and Coleoptera have been found harboring metacercariae of Gorgoderina sp. and Rauschiella repandum (Rudolphi, 1819), respectively, in Venezuela (Lutz 1926, 1928). Natural infection with metacercariae of Stomylotrema vicarium Braun, 1901 (Stomylotrematidae), in aquatic Coleoptera, Megadytes glauca Brullé (Dityscidae), and Heteroptera, Belostoma spp. (Belostomatidae), have been reported in Argentina and Brazil (Ostrowski de Núñez 1978, Digiani 2002, Amato \& Amato 2006).

Over the last decade, studying the biological interactions between insects and trematodes has become important, since metacercariae found in aquatic insects, including Odonata, have been found infected by Neorickettsia risticii (Holland et al. 1985) (Anaplasmataceae), the etiological agent for Potomac Horse Fever (Chae et al. 2000, Madigan et al. 2000, Mott et al. 2002, Gibson \& Rikihisa 2008).

Despite the diversity of species of trematodes found in Brazil, studies involving the possible role of insects in the transmission of these parasites are still needed.

\section{References}

AMATO, S.B. \& AMATO, J.F.R. 2006. Belostoma dilatatum (Dufour) (Hemiptera, Belostomatidae) hospedando metacercárias de Stomylotrema vicarium Braun (Digenea, Stomylotrematidae) na região Sul do Brasil. Rev. Bras. Zool. 23(1):307-310. http://dx.doi.org/10.1590/S010181752006000100028

BRASIL, M.C. \& AMATO S.B. 1992. Faunistic analysis of helminths of sparrows (Passer domesticus L., 1758) captured in Campo Grande, Rio de Janeiro, RJ. Mem. Inst. Oswaldo Cruz 87 (Suppl. I):43-48. http:// dx.doi.org/10.1590/S0074-02761992000500009

BODDEKE, R. 1960. The life history of Prosthogonimus ovatus. II. The intermediate hosts. Trop. Geogr. Med. 12(4):363-377.

BOLEK, M.G. \& JANOVY JR, J. 2007. Evolutionary avenues for, and constraints on, the transmission of frog lung flukes (Haematoloechus spp.) in dragonfly second intermediate hosts. J. Parasitol. 93(3):593-607. PMid:17626352. http://dx.doi.org/10.1645/GE-1011R.1

BOLEK, M.G., TRACY, H.R. \& JANOVY JR, J. 2010. The role of damselflies (Odonata: Zygoptera) as paratenic hosts in the transmission of Halipegus eccentricus (Digenea: Hemiuridae) to anurans. J. Parasitol. 96(4):724735. PMid:20738199. http://dx.doi.org/10.1645/GE-2365.1

BRAUN, M.V. 1901. Zur Kenntnis der Trematoden der Saugethiere. Zool. Jb. Abt. Syst. 14:311-348.

CABALLERO, E.C. \& DÍAZ-UNGRÍA, C. 1958. Intento de un catálogo de los tremátodos digéneos registrados en territorio venezolano. Mem. Soc. Cien. Nat. La Salle 18:19-36.

CALEGARO-MARQUES, C. \& AMATO, S.B. 2010. Helminths of introduced house sparrows (Passer domesticus) in Brazil: does population age affect parasite richness? Iheringia, Ser. Zool. 100(1):73-78. http://dx.doi. org/10.1590/S0073-47212010000100010

CHAE, J.S., PUSTERLA, N., JOHNSON, E., DEROCK, E., LAWLER, S.P. \& MADIGAN, J.E. 2000. Infection of aquatic insects with trematode metacercariae carrying Ehrlichia risticii, the cause of Potomac horse fever. J. Med. Entomol. 37(4):619-625. PMid:10916305. http://dx.doi. org/10.1603/0022-2585-37.4.619

COSTA, J.M. \& SANTOS, T.C. 2009. Description of the larva of Orthemis schmidti (Odonata, Libellulidae). Iheringia, Sér. Zool. 99(2):129-131.

COSTA, J.M., SOUZA, L.O.I. \& OLDRINI, B.B. 2004. Chave de identificação das famílias e gêneros das larvas conhecidas de Odonata do Brasil: comentários e registros bibliográficos (Insecta, Odonata). Pub. Avul. Mus. Nac. 99:1-44.

DIGIANI, M.C. 2002. Belostomatidae (Insecta: Heteroptera) as intermediate hosts of digenetic trematodes. Comp. Parasitol. 69(1):89-92. http://dx.doi. org/10.1654/1525-2647(2002)069[0089:BIHAIH]2.0.CO;2

GIBSON, K.E. \& RIKIHISA, Y. 2008. Molecular link of different stages of the trematode host of Neorickettsia risticii to Acanthatrium oregonense. Environ. Microbiol. 10(8):2064-2073. PMid:18422641. http://dx.doi. org/10.1111/j.1462-2920.2008.01625.x 
HALL, J.E. 1960. Some lecithodendriid metacercariae from Indiana and Michigan. J. Parasitol. 46(3):309-314. http://dx.doi.org/10.2307/3275492

KUMARI, V.G.M.S. \& MADHAVI, R. 1994. The life cycle of Eumegacetes artamii Mehra, 1935 (Trematoda, Eumegacetidae). Acta Parasitol. 39(1):9-12.

LOTZ, J.M. \& FONT, W.F. 2008. Family Eumegacetidae Travassos, 1922. In Keys to the Trematoda, Volume 3. (R.A Bray, D.I. Gibson \& A. Jones, eds.). CAB International and Natural History Museum, London, p.501-504.

LUTZ, A. 1926. Société de Biologie de Rio de Janeiro: Session de 15 de Septembre de 1926. Mem. Inst. Oswaldo Cruz 19(2):237-238. http:// dx.doi.org/10.1590/S0074-02761926000200005

LUTZ, A. 1928. Estudios sobre trematodes observados en Venezuela. In Estúdios de Zoologia y Parasitologia Venezolanas (A. Lutz). Rio de Janeiro, p.101-125.

MADHAVI, R. \& SWARNAKUMARI, V.G.M. 1995. The morphology, life-cycle and systematic position of Orthetrotrema monostomum Macy \& Basch, 1972, a progenetic trematode. Syst. Parasitol. 32(3):225-232. http://dx.doi.org/10.1007/BF00008831

MAdigAn, J.E., PUSTERla, N., JOHNSON, E., CHAE, J.S., PUSTERLA, J.B., DEROCK, E. \& LAWLER, S.P. 2000. Transmission of Ehrlichia risticii, the agent of Potomac horse fever, using naturally infected aquatic insects and helminth vectors: preliminary report. Equine Vet. J. 32(4):275-279. PMid:10952374. http://dx.doi. org/10.2746/042516400777032219

MOTT, J., MURAMATSU, Y., SEATON, E., MARTIN, C., REED, S. \& RIKIHISA, Y. 2002. Molecular analysis of Neorickettsia risticii in adult aquatic insects in Pennsylvania, in horses infected by ingestion of insects, and isolated in cell culture. J. Clin. Microbiol. 40(2):690693. PMid:11825999 PMCid:153368. http://dx.doi.org/10.1128/ JCM.40.2.690-693.2002

OSTROWSKI DE NÚÑEZ, M. 1978. Zum Entwicklungszyklus von Stomylotrema vicarium. Angew. Parasitol. 19:208-213. PMid:736315.
PINTO, H.A. \& MELO, A.L. 2011. A checklist of trematodes (Platyhelminthes) transmitted by Melanoides tuberculata (Mollusca: Thiaridae). Zootaxa 2799:15-28.

PRAKASH, R. \& PANDE, B.P. 1970. Libellulid dragonflies as second intermediate hosts of flukes. Indian J. Helminthol. 21(2):150-160.

RAO, K.H. \& MADHAVI, R. 1961. Metacercaria of Eumegacetes sp. (Trematoda: Lecithodendriidae) in dragon-fly naiads from a stream at Waltair. Curr. Sci. 30(8):303-304.

SANTOS, N.D. 1973. Contribuição ao conhecimento da fauna do Estado da Guanabara e arredores. 84 - Descrição da ninfa de Perithemis mooma Kirby, 1889 (Odonata: Libellulidae). Atas Soc. Biol. Rio de Janeiro 16:71-72.

SINGH, P. \& PANDE, B.P. 1968. Adult of Eumegacetes artamii from white leghorn pullets infected with the metacercariae from two dragonflies. Curr. Sci. 37(19):563-564.

SINITSIN, D.T. 1905. Data on the natural history of trematodes. Distomes of fishes and frogs in the vicinity of Warsaw. Warsaw University, Warsaw.

SNYDER, S.D. \& JANOVY JR, J. 1994. Second intermediate host-specificity of Haematoloechus complexus and Haematoloechus medioplexus (Digenea: Haematoloechidae). J. Parasitol. 80(6):1052-1055. http:// dx.doi.org/10.2307/3283461

STAFFORD, E.W. 1931. Platyhelmia in aquatic insects and Crustacea. J. Parasitol. 18:131.

TRAVASSOS, L. 1928. Fauna helmintológica do Mato Grosso (Trematódeos - $1^{\text {a }}$ parte). Mem. Inst. Oswaldo Cruz 21(2):309-341. http://dx.doi.org/10.1590/S0074-02761928000200002

TRAVASSOS, L. \& FREITAS, J.F.T. 1940. Relatório da excursão científica realizada na zona da Estrada de Ferro Noroeste do Brasil em julho de 1939. Mem. Inst. Oswaldo Cruz 35(3):525-556. http://dx.doi. org/10.1590/S0074-02761940000300004

TRAVASSOS, L., FREITAS J.F.T. \& KOHN, A. 1969. Trematódeos do Brasil. Mem. Inst. Oswaldo Cruz 67:1-886. PMid:5397756.

ZELMER, D.A. \& ESCH, G.W. 1998. Bridging the gap: the odonate naiad as a paratenic host for Halipegus occidualis (Trematoda: Hemiuridae). J. Parasitol 84(1):94-96. http://dx.doi.org/10.2307/3284536 